\title{
IMPROVING THE LOAD CARRYING CAPACITY OF SQUARE FOOTING RESTING ON REINFORCED SAND
}

\author{
Sangameshwar Patil ${ }^{1}$, P.G Rakaraddi ${ }^{2}$ \\ ${ }^{1}$ Post -Graduate student ,Department of Geotechnical Engineering, Basaveshwar Engineering college, Bagalkot, \\ Karnataka, India \\ ${ }^{2}$ Professor in civil dept, Basaveshwar Engineering college, Bagalkot, Karnataka, India
}

\begin{abstract}
The rapid growth of the big cities in the vertical direction leads to essentially of strengthening of low bearing capacity areas as the cost of land is very high and also, the disposal of the plastic wastes such as plastic bottles, bags etc. is a big problem and environmental hazards in such areas. The waste plastic bottles as geotechnical material are used to solve both geotechnical and environmental problems. The laboratory investigations are carried out to evaluate the effect of waste plastic bottles as soil reinforcement for improving bearing capacity of soil. The bearing capacity of square footing on sandy soil reinforced with waste plastic water bottles for different L/D ratio, number of layers and for different densities of foundation soil is evaluated through model test. The increase in the bearing capacity with the provision of waste plastic bottle as reinforcement is observed.
\end{abstract}

Keywords: Sand, Ultimate load, Settlement, Reinforcement, U/B ratio, L/D ratio.

\section{INTRODUCTION}

The footing resting on weak soils like sand having low bearing capacity exhibits large settlements under small loads. For such weak soils with large loading condition raft foundation is preferred which increase the load bearing capacity of such soils. But there are some problems will arise with raft foundation as the excavation of large area is not economical and also if the construction is adjacent to old structures and the foundation depth is large then the excavation area has to be braced during foundation construction. For this purpose many researchers (Sujit Kumar et.al. 2001[1], Sujit Kumar et.al. 2003[2],) investigated that providing reinforcement for soil increases the bearing capacity. The speciality of reinforcement is its flexibility, which enables construction on poor foundation soil, rapid construction and low cost.

Geosynthetics as reinforcement for improving the performance of shallow foundations has been studied by many engineers (Sireesh et.al.2009 [4], Kumar et.al. 2012[7]) from past two decades. The use of plastic products, such as polythene bags, bottles, containers and packaging strips, is increasing day by day and their disposal is problematic. In this project laboratory model plate load test on square footing resting on sand bed reinforced with waste plastic bottles is tested for different parameters by varying L/D ratio of reinforcement, number of layers, density of sand etc. The laboratory test results show that the use of waste bottles as reinforcement leads to increase in the bearing capacity.

\section{LITERATURE}

Many research works has been carried out on effects of using reinforcement in soil such as geotextile and geogrid.
The increase in the bearing capacity of strip and circular footing resting on the geocell as reinforcement is almost 8 times the unreinforced case (Sujit Kumar et.al, 2001, Sujit Kumar et.al, 2003, Al- Aghbari, 2007. Sireesh et.al. (2009) carried out tests on circular footing on geocell, the test results indicated that improvement in bearing capacity, Gupta and Trivedi (2009) investigated on circular footing resting on circular confinement with different diameter and different height, from the test results concluded that providing confinement improves bearing capacity, Moghaddas Tafreshi and Dawson (2010) investigated on strip footing on sand with geocell and geotextile, from the results concluded that improvement in bearing capacity, Kumar et.al (2012) investigated on square footing resting on geocell sand mattress and concluded that bearing capacity increases with the provision of reinforcement below the footing, Krishna et.al (2014) carried out tests on square footing confined with steel casing and concluded that load carrying capacity of the footing increases due to confinement below the footing, Gupta et al. (2014a), Chandrawanshi et al. (2014), Gupta et al. (2014b) carried out investigation on confinement below the footing and results shows that increase in the bearing capacity by providing confinement to the soil.

\section{METHODOLOGY}

The Malaprabha river from Bagalkot district, Karnataka, sand is used as foundation soil medium. The properties of the sand are given in table 1 . From the laboratory test results, according to IS 2720 part 4 if $\mathrm{C}_{\mathrm{u}}<6$ and $\mathrm{C}_{\mathrm{c}}<1$ then the soil is classified as poorly graded sand. The square footing of $100 \mathrm{~mm} \times 100 \mathrm{~mm}$ and thickness $10 \mathrm{~mm}$ is tested on the sand bed of different densities filled in the testing tank of size $600 \mathrm{~mm} \times 600 \mathrm{~mm} \times 600 \mathrm{~mm}$ by raining technique method. To attain the densities of $16.57 \mathrm{kN} / \mathrm{m}^{3}$, 
$17.16 \mathrm{kN} / \mathrm{m}^{3}$ and $17.36 \mathrm{kN} / \mathrm{m}^{3}$, the sand is made to fall from different heights. Waste plastic bottles are cut for different $\mathrm{L} / \mathrm{D}$ ratios as given in table 2 are used as reinforcement material. The cut plastic bottles were join together using the wire and placed in the foundation soil while preparing the bed (i) in one layer at a depth of $0.35 \mathrm{U} / \mathrm{B}$ ratio, (ii) second layer at a depth of $82.5 \mathrm{~mm}$ from the first layer and (iii) while placing the third layer the thickness of second and third layer are kept constant as $55 \mathrm{~mm}$. The experimental setup is shown in fig.2. Vertical load is applied on footing using screw jack of 5 tonne capacity is measured using proving ring and the settlement of the footing is measured by two LVDT placing diagonally on the footing.

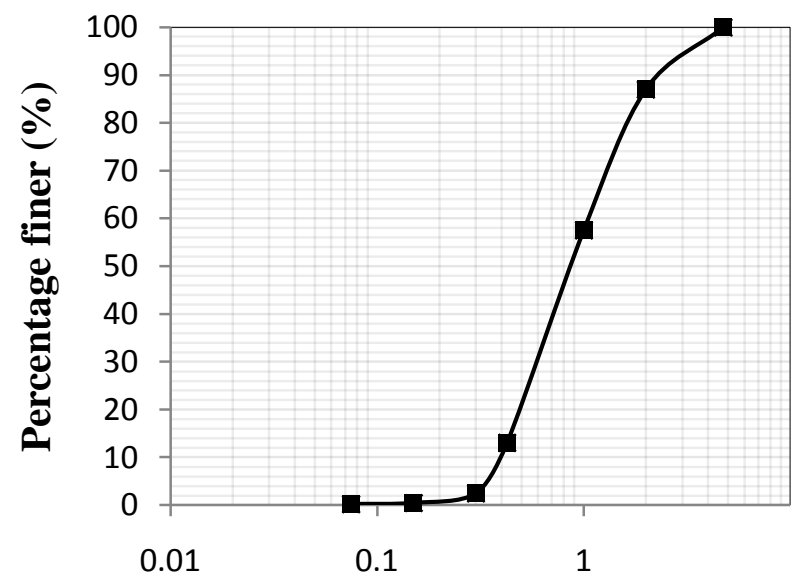

Particle size (mm)

Fig-1: Particle size distribution characteristics of sand used in the study

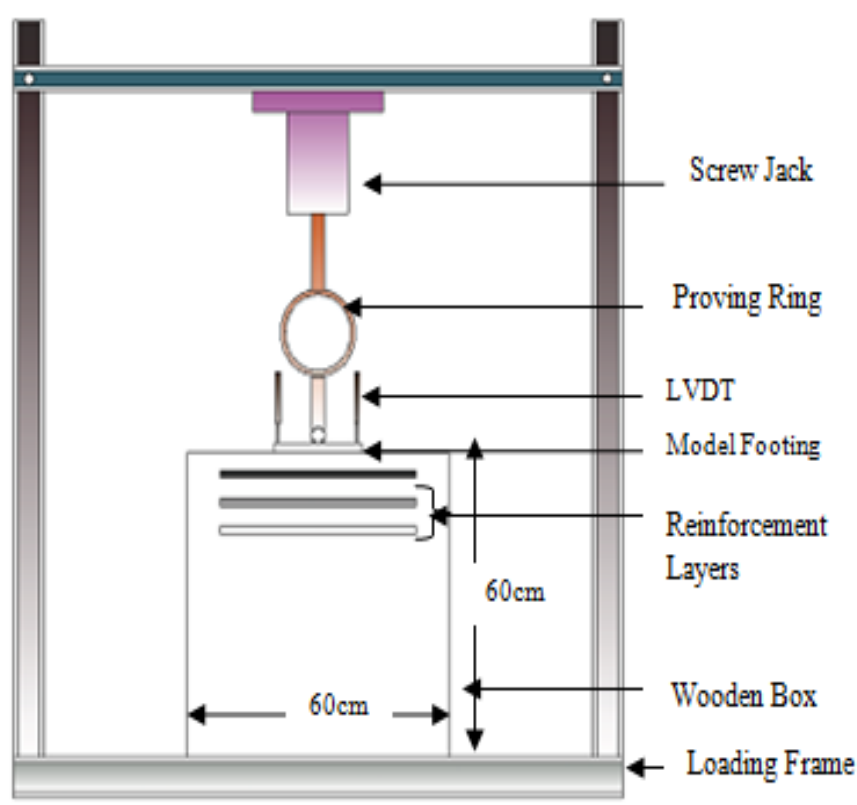

Fig 2-: Line diagram of experimental setup
Table -1: Properties of sand used in the study

\begin{tabular}{|l|l|}
\hline Property & Value \\
\hline Specific gravity $(\mathrm{G})$ & 2.59 \\
\hline Grain size analysis & 0.35 \\
$\mathrm{D}_{10}, \mathrm{~mm}$ & 0.48 \\
$\mathrm{D}_{30}, \mathrm{~mm}$ & 0.72 \\
$\mathrm{D}_{50}, \mathrm{~mm}$ & 0.98 \\
$\mathrm{D}_{60}, \mathrm{~mm}$ & \\
Coefficient of uniformity, & 2.8 \\
$\left(\mathrm{C}_{\mathrm{u})}\right.$ & \\
Coefficient of curvature, $\left(\mathrm{C}_{\mathrm{c}}\right)$ & 0.67 \\
I.S. Classification & Poorly \\
& graded \\
\hline $\begin{array}{l}\text { Maximum dry unit weight, } \\
\left(\mathrm{kN} / \mathrm{m}^{3}\right)\end{array}$ & 17.75 \\
Minimum dry unit weight, & 15.59 \\
$\left(\mathrm{kN} / \mathrm{m}^{3}\right)$ & \\
Maximum void ratio, $\left(\mathrm{e}_{\max }\right)$ & 0.62 \\
Minimum void ratio, $\left(\mathrm{e}_{\min }\right)$ & 0.43 \\
\hline Angle of internal friction & \\
$($ degrees) for different & \\
densities & \\
$\gamma=16.57\left(\mathrm{kN} / \mathrm{m}^{3}\right)$ & $34^{0}$ \\
$\gamma=17.16\left(\mathrm{kN} / \mathrm{m}^{3}\right)$ & $36^{0}$ \\
$\gamma=17.36\left(\mathrm{kN} / \mathrm{m}^{3}\right)$ & $40^{0}$ \\
& \\
\hline
\end{tabular}

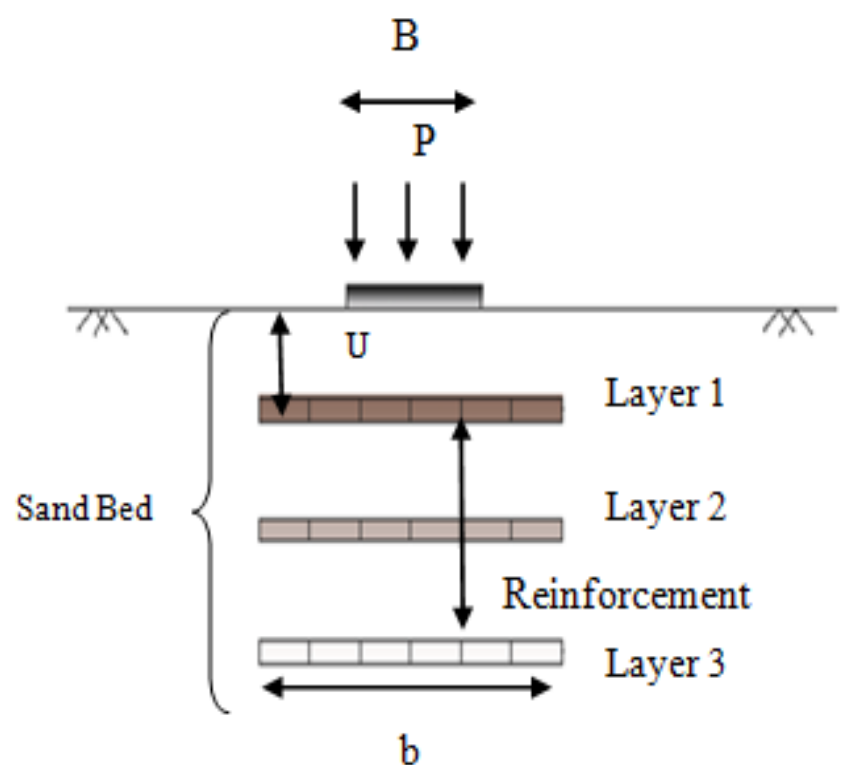

Fig -3: Layout and configuration three dimensional reinforcement layers in the test.

Table -2: Different L/D ratio of reinforcement

\begin{tabular}{|l|l|l|l|}
\hline Sl.no & $\begin{array}{l}\text { Diameter } \\
\text { of bottles } \\
\text { (D) }\end{array}$ & $\begin{array}{l}\text { Length of } \\
\text { bottles } \\
\text { (L) }\end{array}$ & $\begin{array}{l}\text { L/D } \\
\text { ratio }\end{array}$ \\
\hline 1 & $75 \mathrm{~mm}$ & $15 \mathrm{~mm}$ & 0.20 \\
\hline 2 & $75 \mathrm{~mm}$ & $20 \mathrm{~mm}$ & 0.26 \\
\hline 3 & $75 \mathrm{~mm}$ & $25 \mathrm{~mm}$ & 0.33 \\
\hline 4 & $75 \mathrm{~mm}$ & $30 \mathrm{~mm}$ & 0.40 \\
\hline
\end{tabular}


The U/B ratio corresponding to depth first reinforcement was given in table 3 .

Table -3: U/B ratio corresponding first reinforcement depth

\begin{tabular}{|l|l|}
\hline U/B ratio & $\begin{array}{l}\text { First reinforcement } \\
\text { Depth }(\mathbf{U})\end{array}$ \\
\hline 0.30 & $30 \mathrm{~mm}$ \\
\hline 0.35 & $35 \mathrm{~mm}$ \\
\hline 0.40 & $40 \mathrm{~mm}$ \\
\hline 0.45 & $45 \mathrm{~mm}$ \\
\hline
\end{tabular}

\section{RESULTS AND DISCUSSION}

\subsection{Loading on Un-Reinforced Sand}

The load carrying capacity of soil resting on square footing for unreinforced soil for density $16.57 \mathrm{kN} / \mathrm{m}^{3}, 17.16 \mathrm{kN} / \mathrm{m}^{3}$ and $17.36 \mathrm{kN} / \mathrm{m}^{3}$ is $0.22 \mathrm{kN}, 0.3 \mathrm{kN}$ and $0.40 \mathrm{kN}$ respectively.

\subsection{Effect of U/B Ratio on Ultimate Bearing Capacity of the Square Footing Resting on Reinforced Sand}

The load settlement curve for the density $16.57 \mathrm{kN} / \mathrm{m}^{3}$ is shown in fig 4 for U/B ratio of $0.30,0.35,0.40$ and 0.45 for waste bottle reinforcement. The ultimate load is determined by double tangent method (IS 1888/1982 [15]) and the values are exclusively given in table 4 for all the densities of $16.57 \mathrm{kN} / \mathrm{m}^{3}, 17.16 \mathrm{kN} / \mathrm{m}^{3}$ and $17.36 \mathrm{kN} / \mathrm{m}^{3}$.

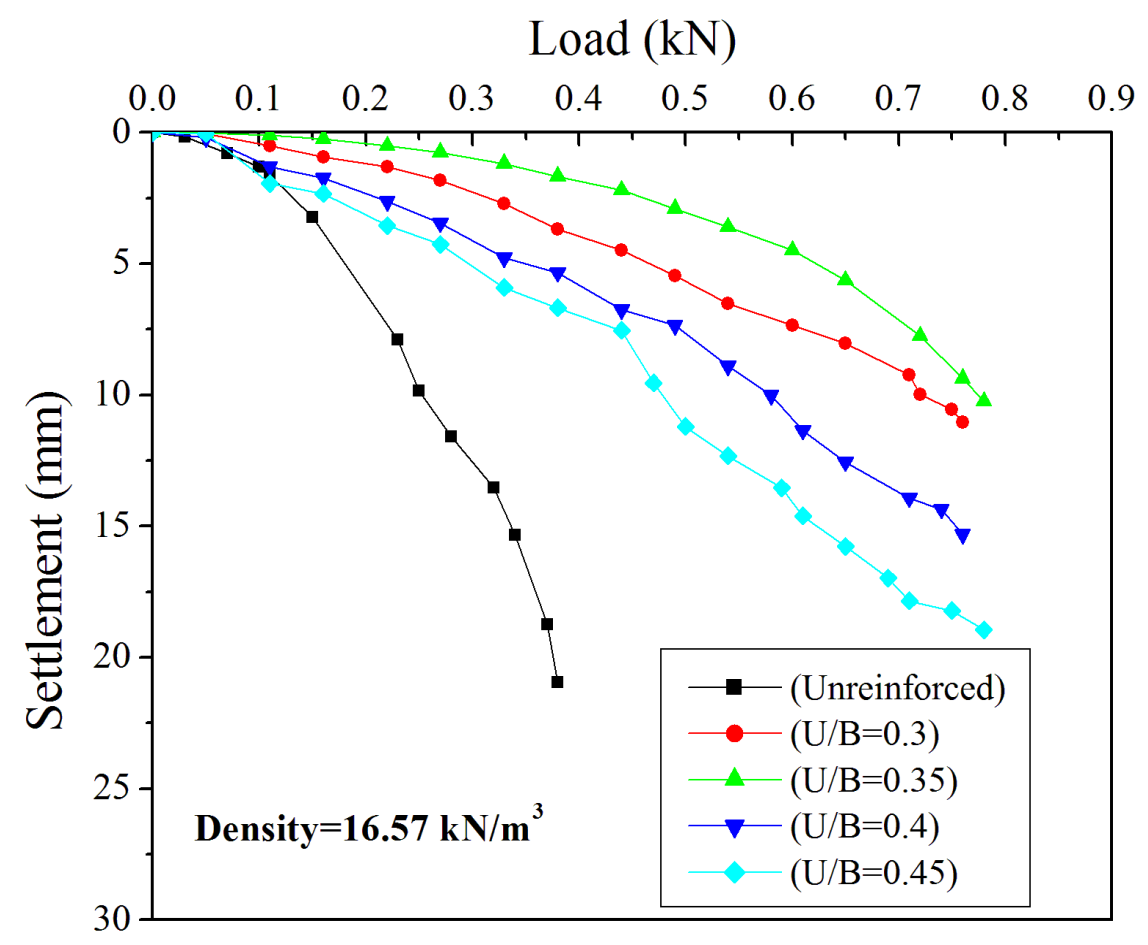

Fig-4: Load - Settlement curves for L/D ratio 0.2 for different U/B ratio

Table-4: Ultimate bearing capacity of reinforced sand for different densities and U/B ratio.

\begin{tabular}{|l|l|l|l|}
\hline \multirow{2}{*}{ U/B ratio } & \multicolumn{3}{|l|}{ Ultimate Load (kN) for the density of } \\
\cline { 2 - 4 } & $\begin{array}{l}16.57 \\
\mathrm{kN} / \mathrm{m}^{3}\end{array}$ & $\begin{array}{l}17.16 \\
\mathrm{kN} / \mathrm{m}^{3}\end{array}$ & $\begin{array}{l}17.36 \\
\mathrm{kN} / \mathrm{m}^{3}\end{array}$ \\
\hline 0.30 & 0.32 & 0.50 & 0.61 \\
\hline 0.35 & 0.50 & 0.58 & 1.03 \\
\hline 0.40 & 0.28 & 0.51 & 0.65 \\
\hline 0.45 & 0.25 & 0.45 & 0.48 \\
\hline
\end{tabular}

The ultimate load carrying capacity increases with the density of the soil and also with the provision reinforcement. The value of $\mathrm{q}_{\text {ult }}$ for $\mathrm{U} / \mathrm{B}=0.35$ is $0.5 \mathrm{kN}, 0.58$ and 1.03 for the densities $16.57 \mathrm{kN} / \mathrm{m}^{3}, 17.16 \mathrm{kN} / \mathrm{m}^{3}$ and $17.36 \mathrm{kN} / \mathrm{m}^{3}$ which is much greater than the U/B of $0.30,0.40$ and 0.45 . The strength of the soil depends mainly on position of reinforcement within the influencing depth below the footing. 


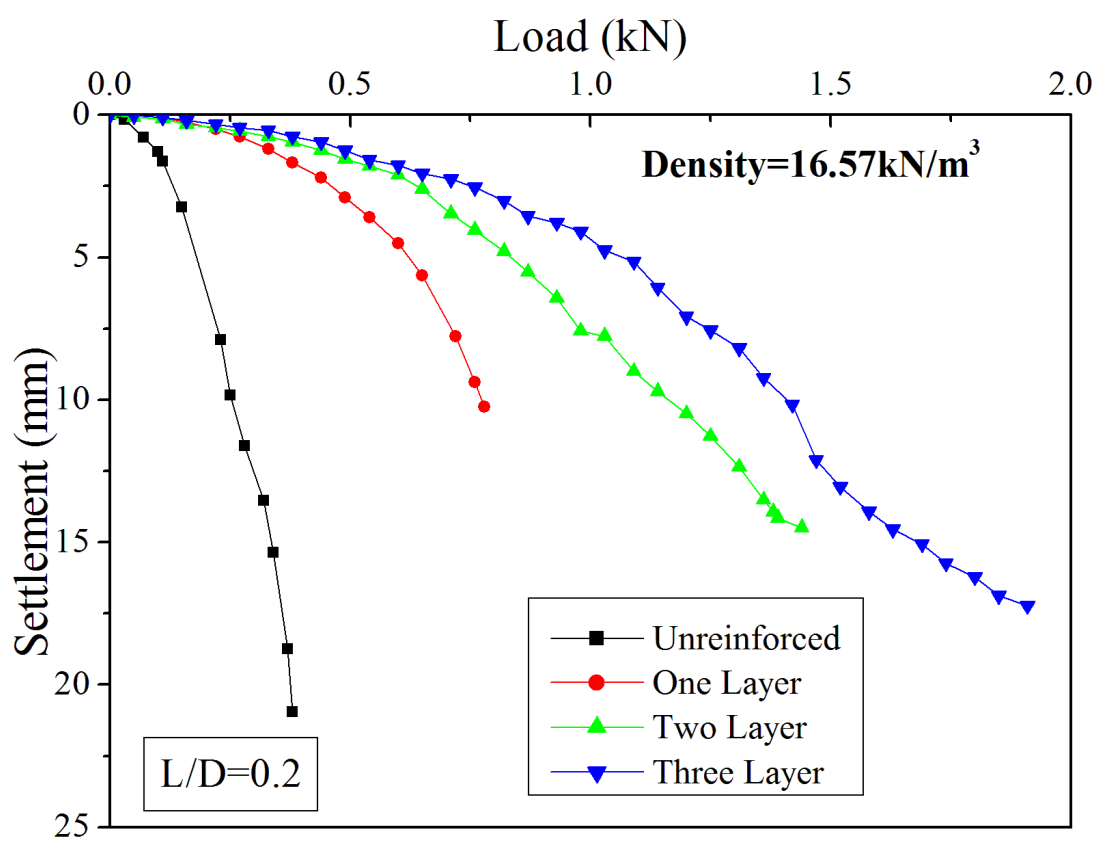

(a)

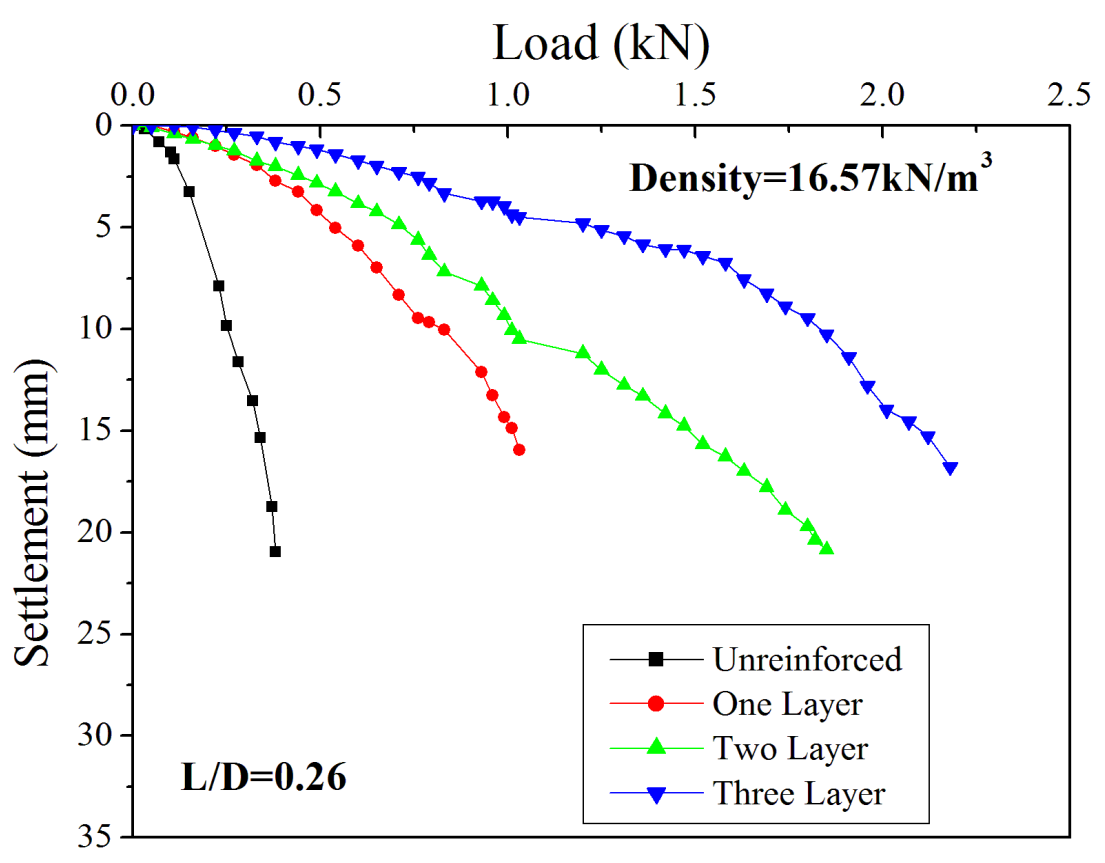

(b) 


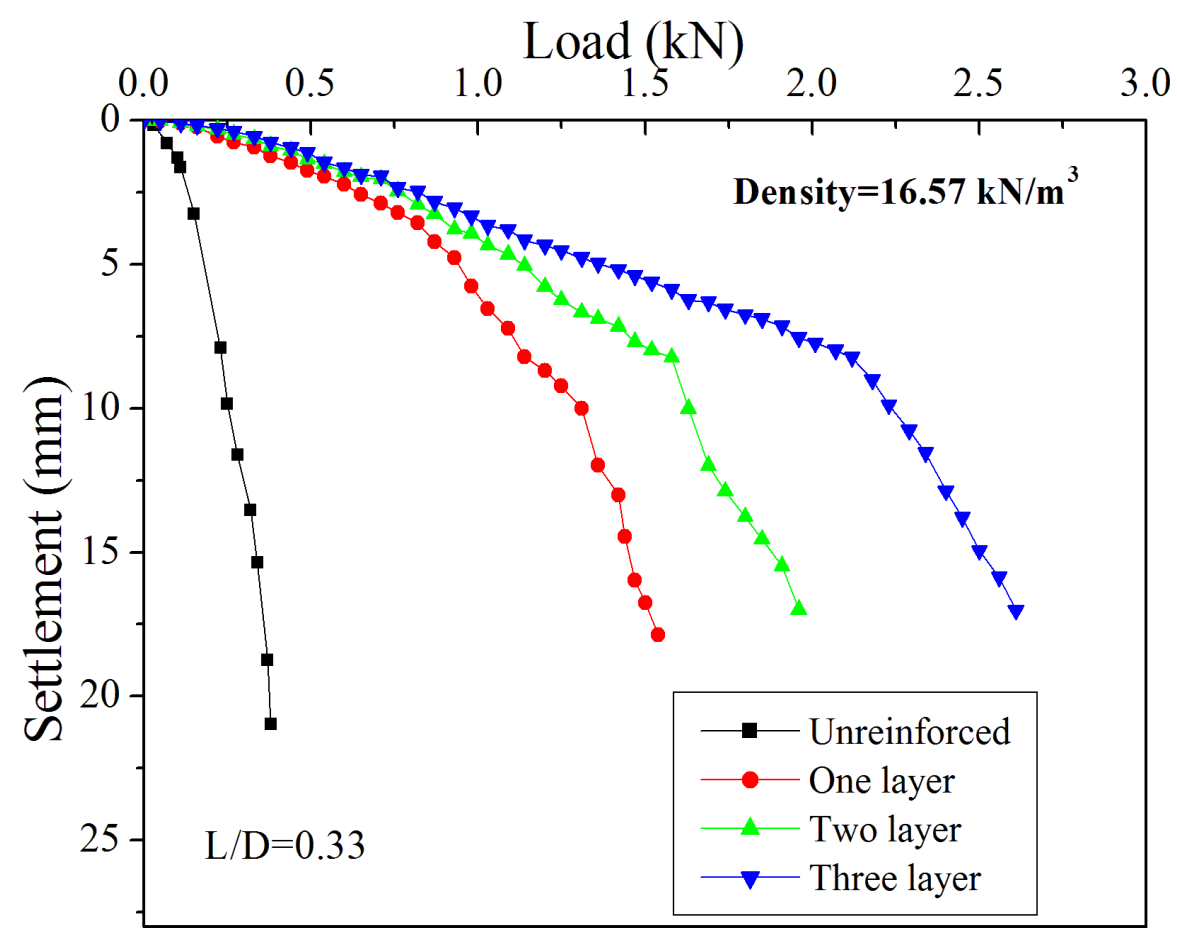

(c)

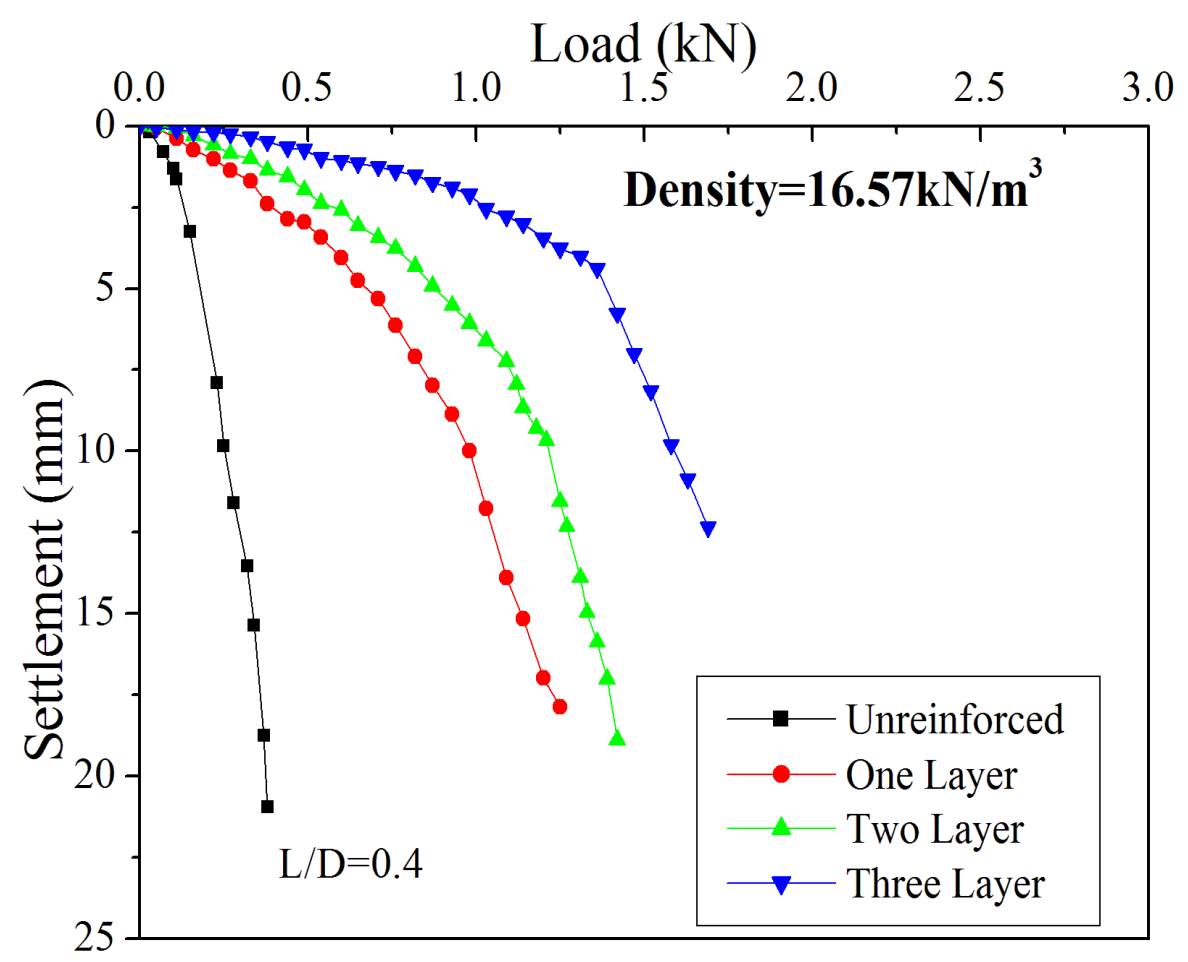

(d)

Fig-5: Load - Settlement curves for the density of $16.57 \mathrm{kN} / \mathrm{m}^{3}$ and L/D ratio (a) 0.20 (b) 0.26 (c) 0.33 and (d) 0.40

Figure 5 show the variation of the load with settlement for the density $16.57 \mathrm{kN} / \mathrm{m}^{3}$ and for different layers of reinforcement. The figure (a), (b), (c) and (d) show the variation of the load with settlement for the L/D ratio 0.20 , $0.26,0.33$ and 0.40 respectively. Figure 6 shows the variation of the load with settlement for the density of
$17.16 \mathrm{kN} / \mathrm{m}^{3}$ and for different layers of reinforcement. The figure (a), (b), (c) and (d) show the variation for the L/D ratio of $0.20,0.26,0.33$ and 0.40 respectively. 


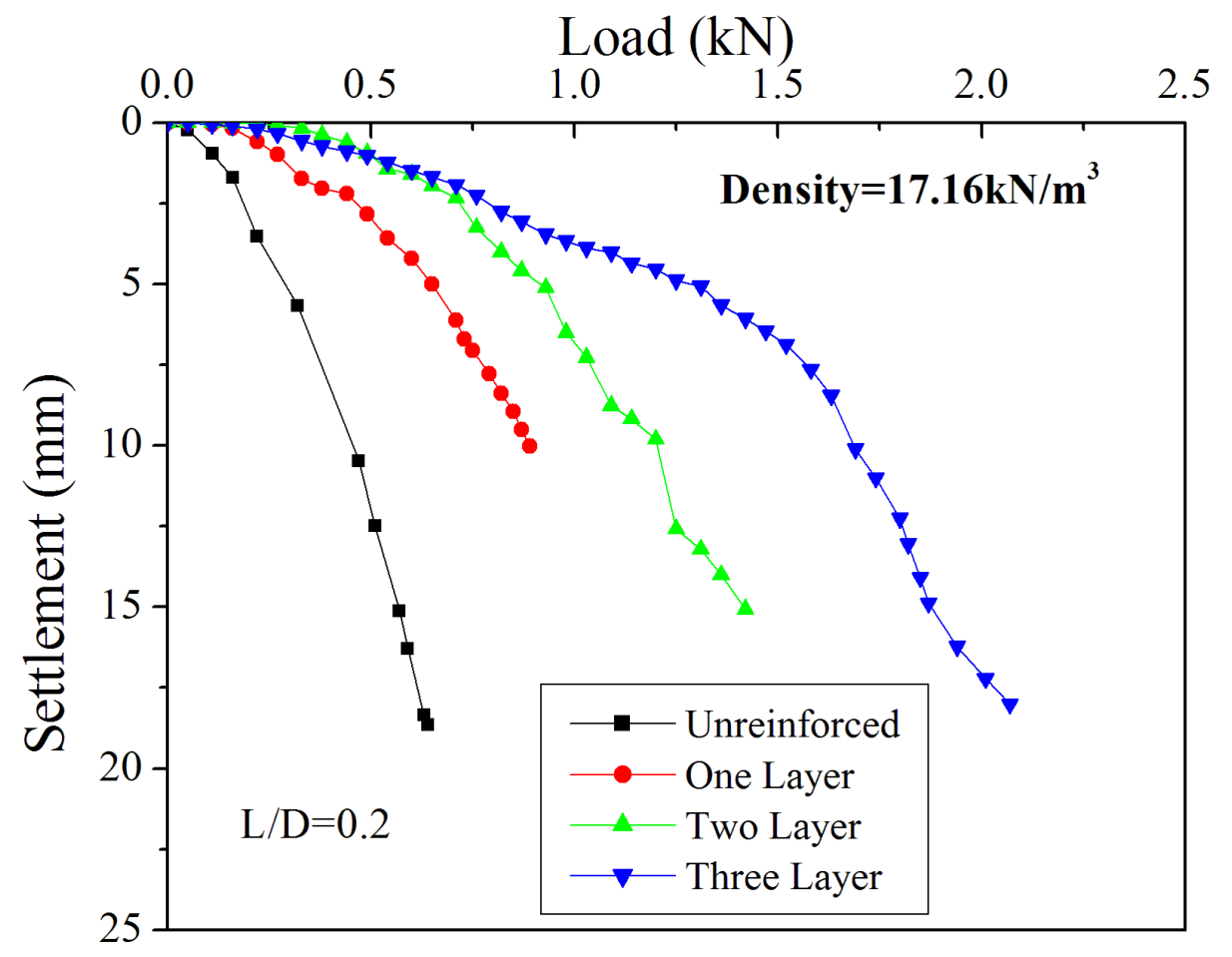

(a)

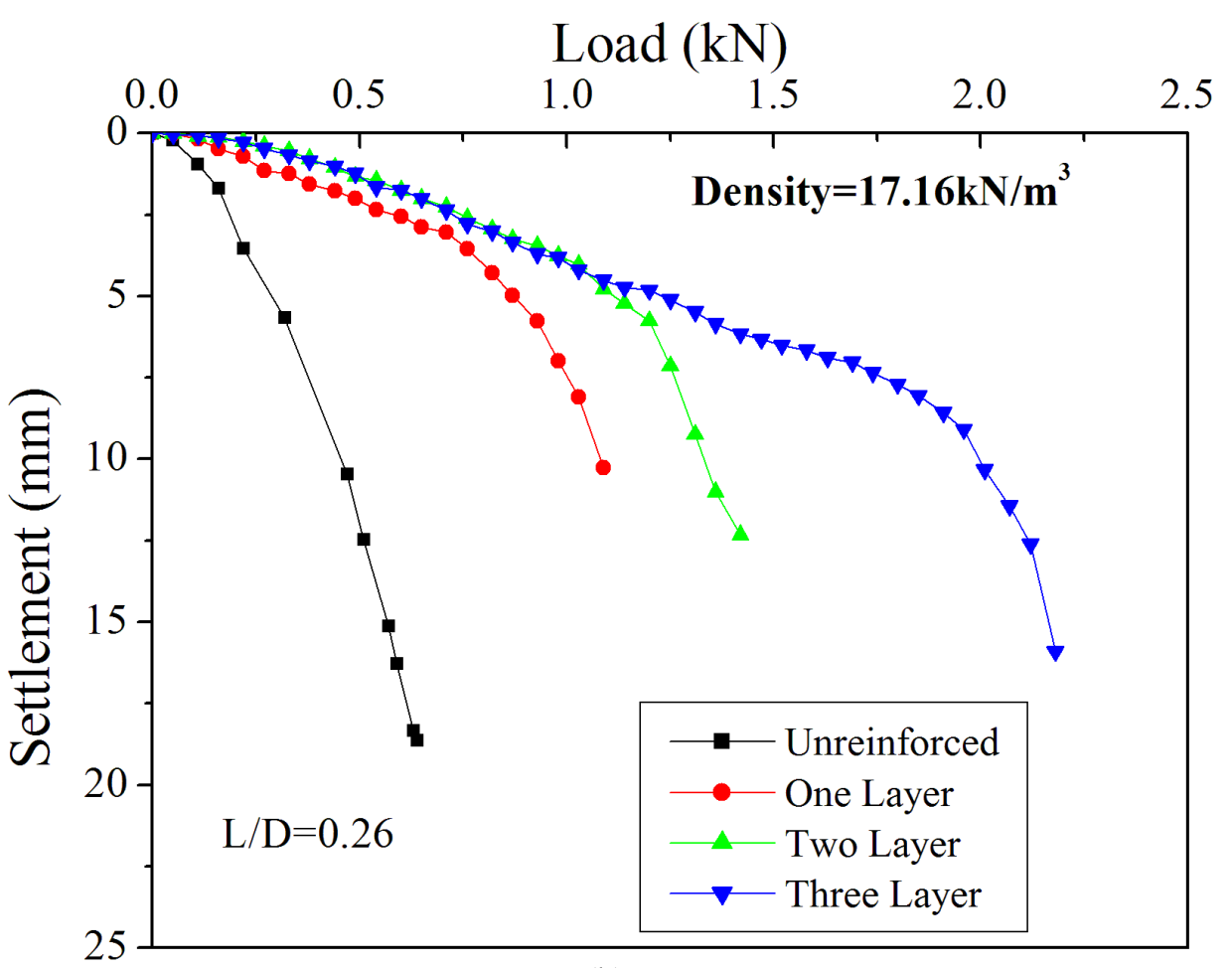

(b) 


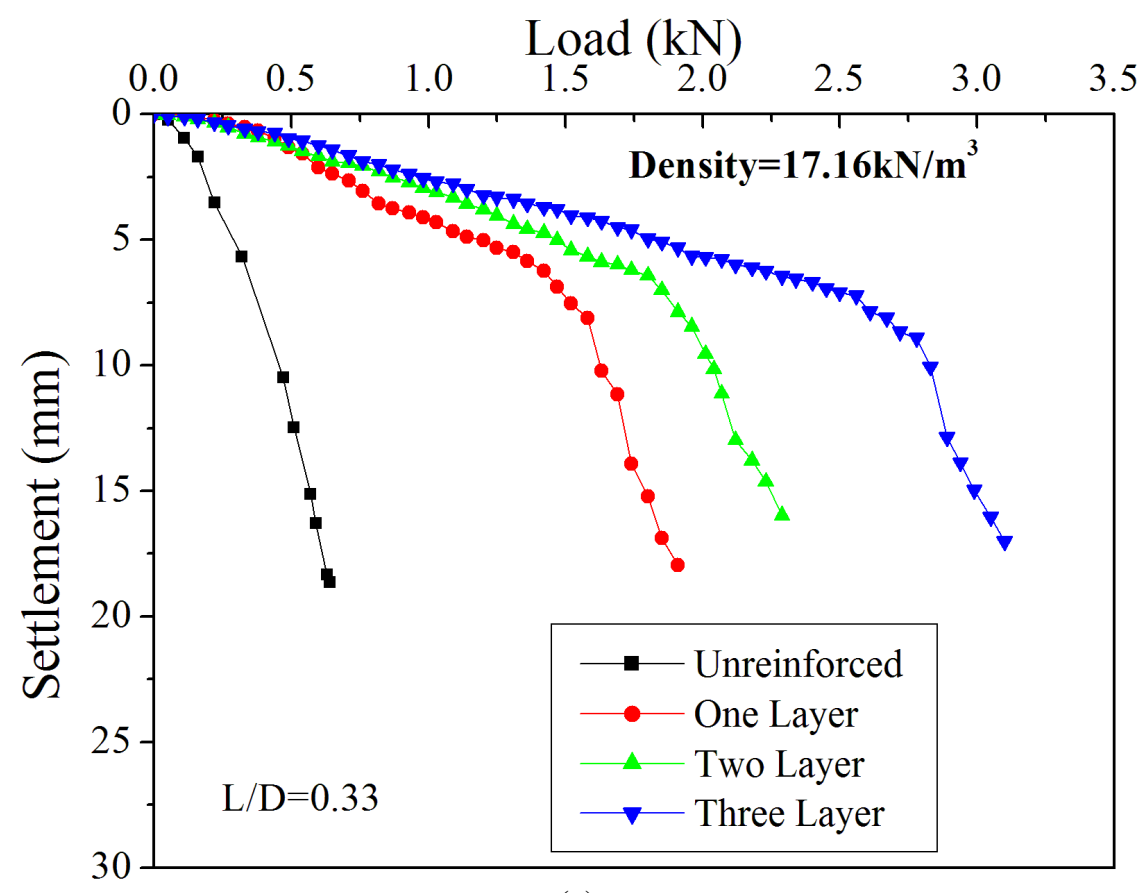

(c)

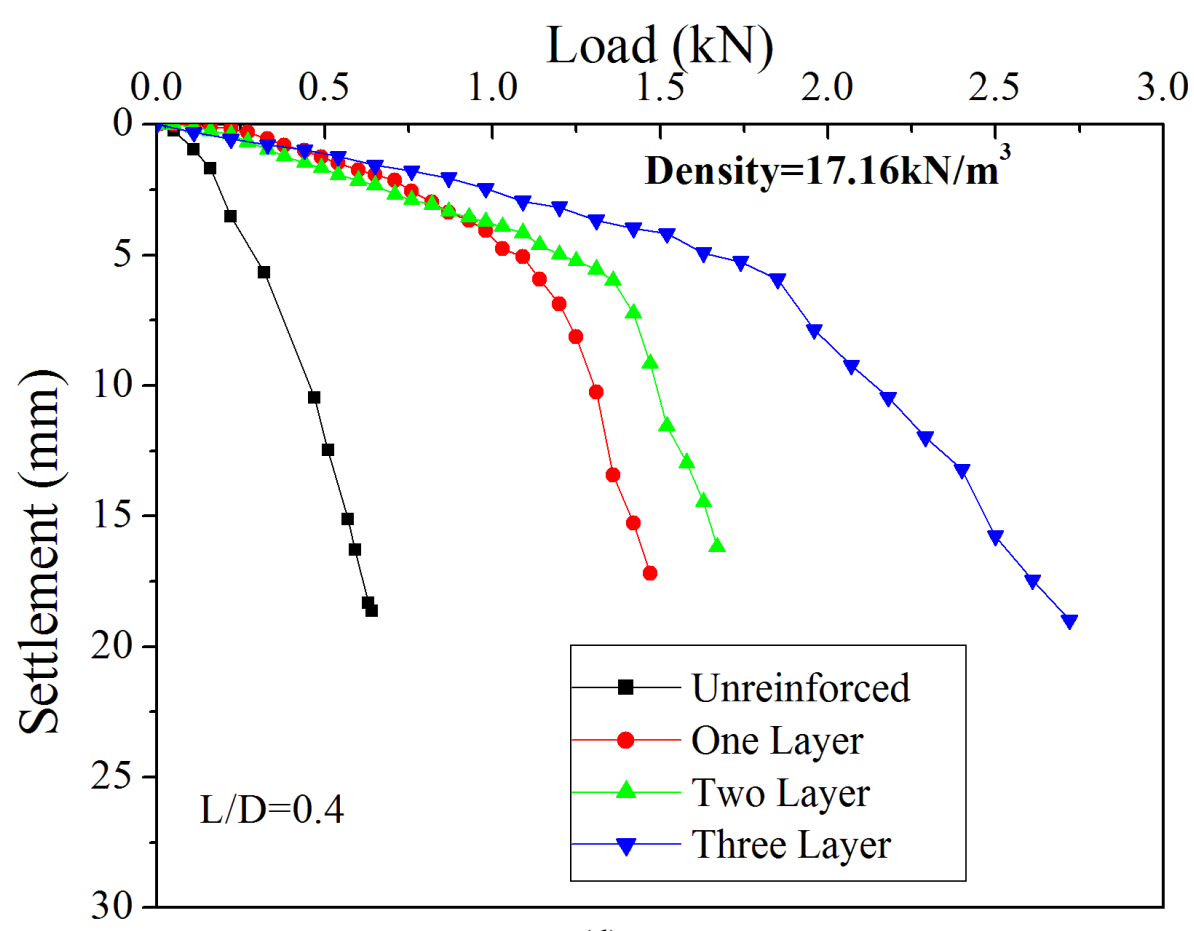

(d)

Fig -6: Load - Settlement curves for density of $17.16 \mathrm{kN} / \mathrm{m}^{3}$ and L/D ratio (a) 0.20 (b) 0.26 (c) 0.33 and (d) 0.40

Figure 6 shows the variation of the load with settlement for the density of $17.16 \mathrm{kN} / \mathrm{m}^{3}$ and for different layers of reinforcement. The figure (a), (b), (c) and (d) show the variation for the $\mathrm{L} / \mathrm{D}$ ratio of $0.20,0.26,0.33$ and 0.40 respectively. 


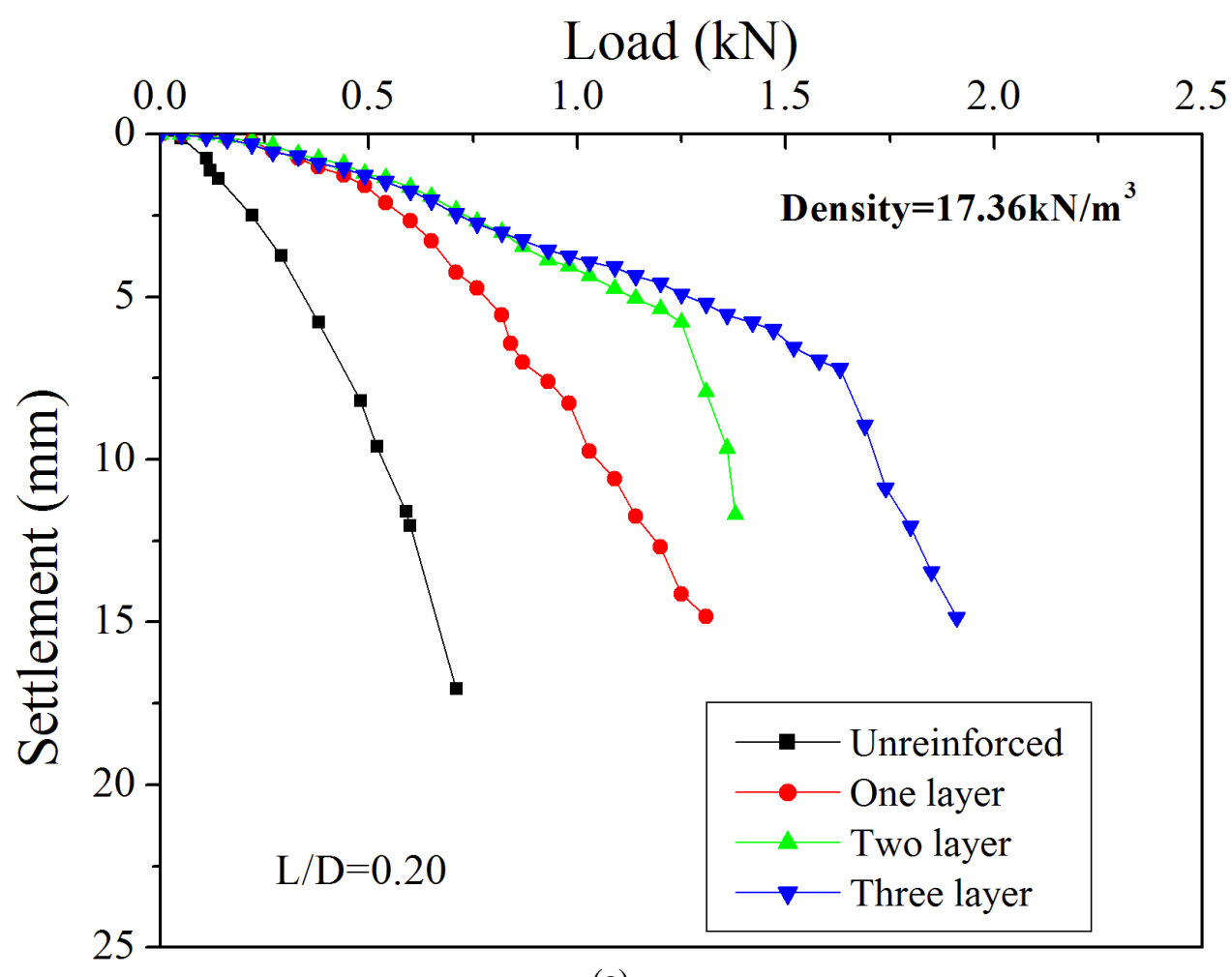

(a)

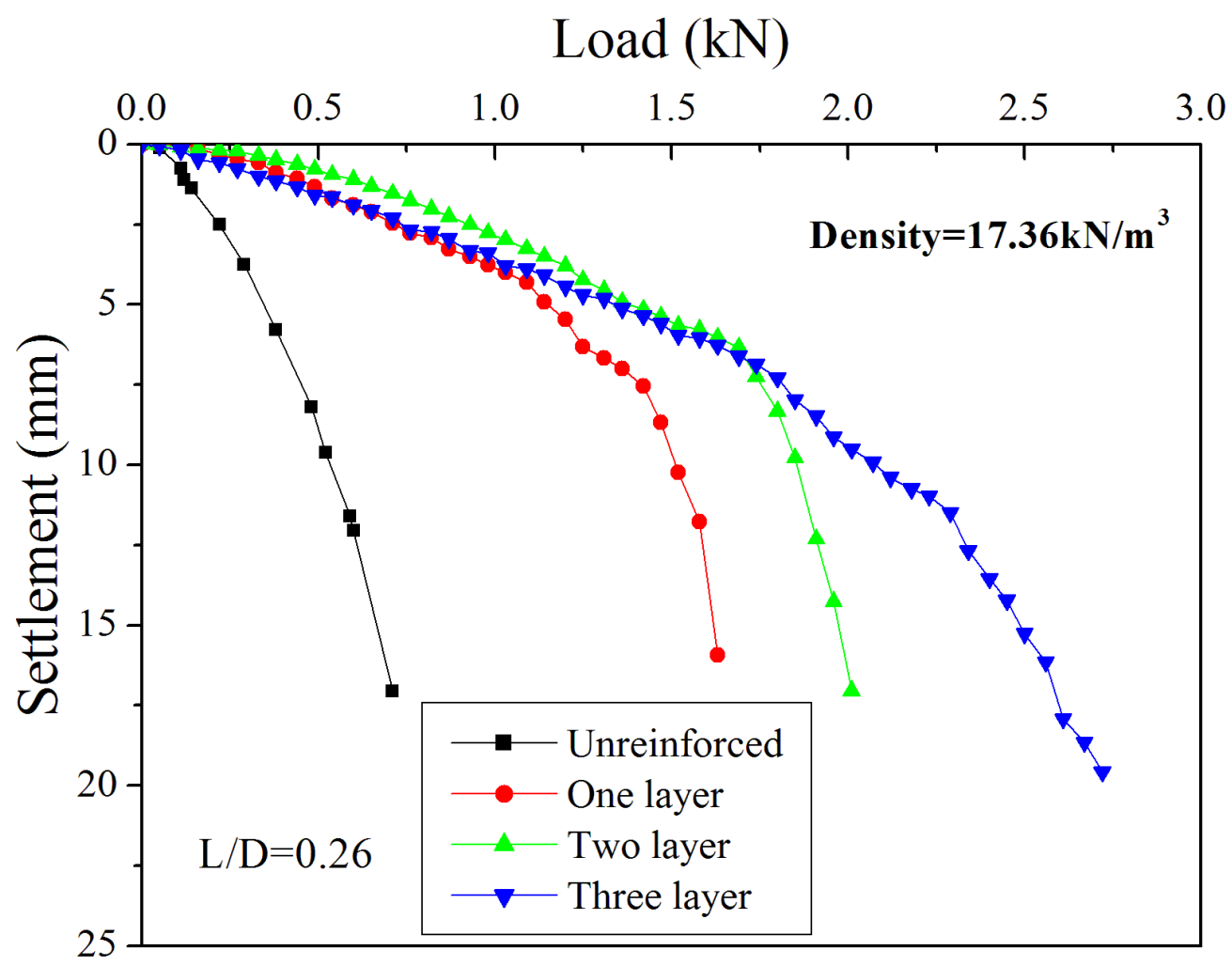

(b) 


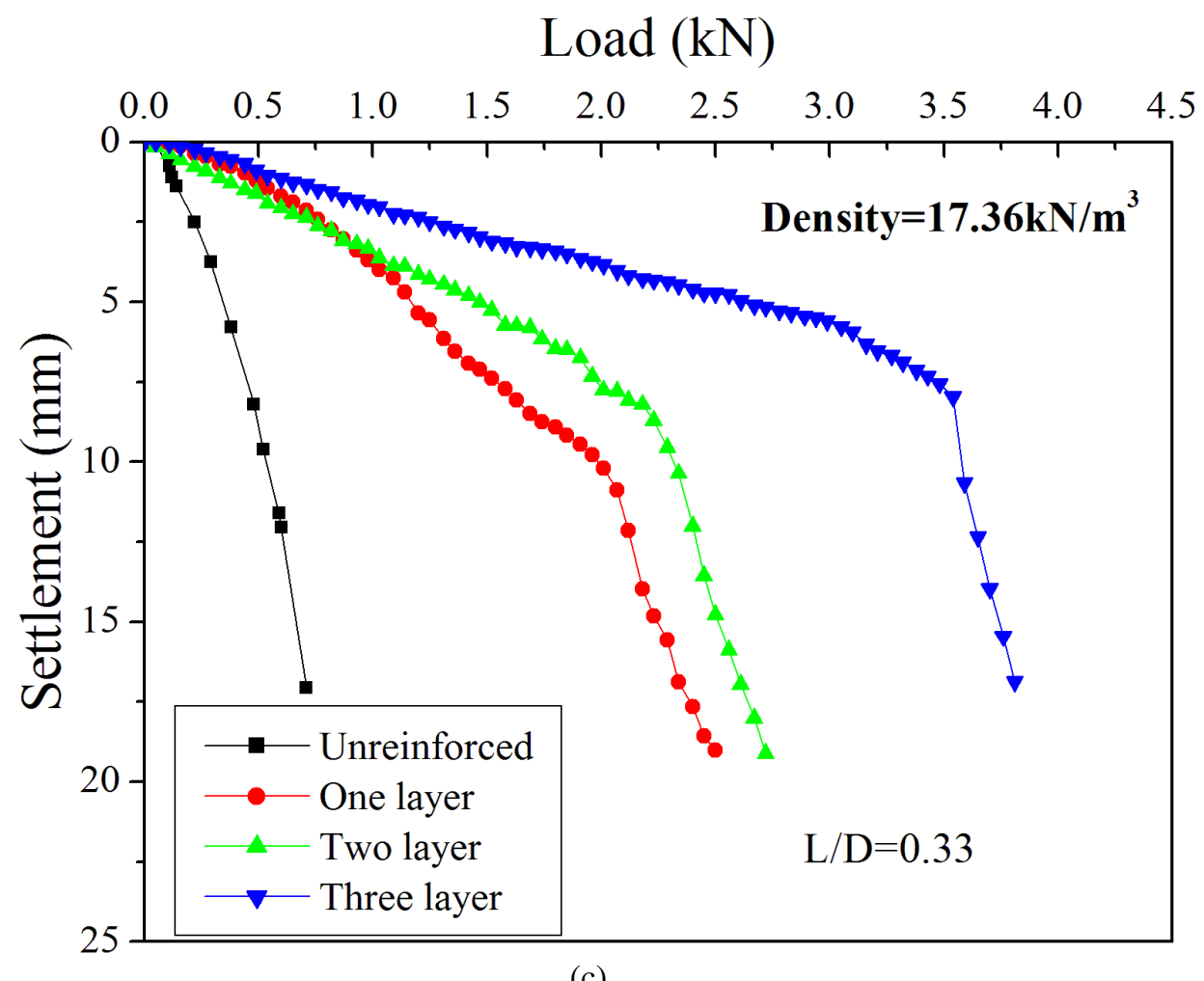

(c)

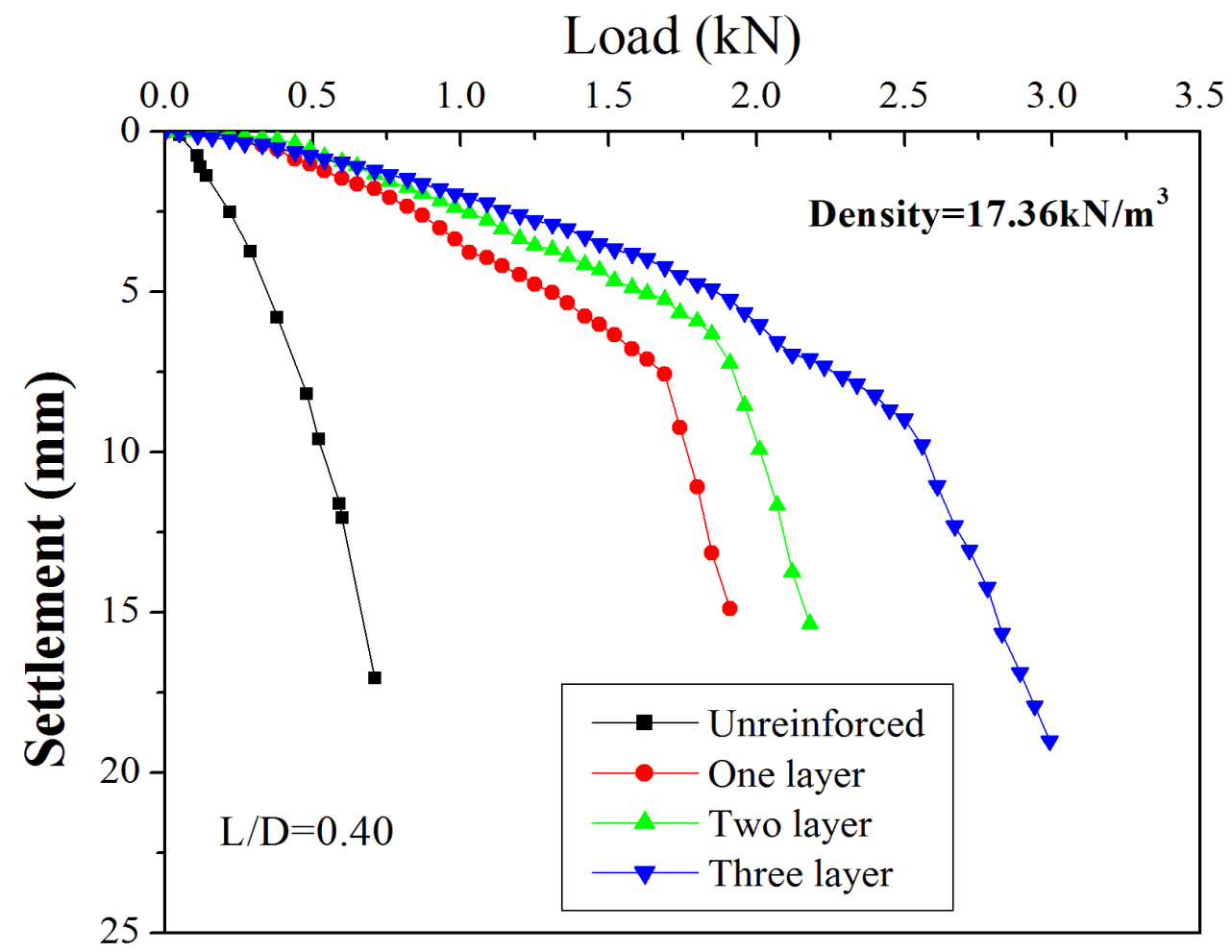

(d)

Fig-7: Load - Settlement curves for the density of $17.36 \mathrm{kN} / \mathrm{m}^{3}$ and L/D ratio (a) 0.20 (b) 0.26 (c) 0.33 and (d) 0.40

Figure 7 shows the variation of the load with settlement for the density of $17.36 \mathrm{kN} / \mathrm{m}^{3}$ and for different layers of reinforcement. The figure (a), (b), (c) and (d) show the variation for the $\mathrm{L} / \mathrm{D}$ ratio of $0.20,0.26,0.33$ and 0.40 respectively.
From figures 5, 6 and 7 and table 5, the ultimate load for the density of $16.57 \mathrm{kN} / \mathrm{m}^{3}, 17.16 \mathrm{kN} / \mathrm{m}^{3}$, and $17.36 \mathrm{kN} / \mathrm{m}^{3}$ and $\mathrm{L} / \mathrm{D}$ ratio $0.20,0.26,0.33$ and 0.40 for three layer reinforcement is respectively (i) $0.9 \mathrm{kN}, 1.40 \mathrm{kN}, 1.83 \mathrm{kN}$ and $1.23 \mathrm{kN}$ (ii) $1.32 \mathrm{kN}, 1.90 \mathrm{kN}, 2.45 \mathrm{kN}$ and $1.80 \mathrm{kN}$ and 
(iii) $1.50 \mathrm{kN}, 2.04 \mathrm{kN}, 3.40 \mathrm{kN}$ and $2.28 \mathrm{kN}$ whereas for one layer is (i) $0.5 \mathrm{kN}, 0.60 \mathrm{kN}, 1.05 \mathrm{kN}$ and $0.74 \mathrm{kN}$ (ii) 0.58 $\mathrm{kN}, 0.77 \mathrm{kN}, 1.45 \mathrm{kN}$ and $1.10 \mathrm{kN}$ (iii) $1.03 \mathrm{kN}, 1.42 \mathrm{kN}$, $1.70 \mathrm{kN}$ and $1.51 \mathrm{kN}$ and for two layer is (i) $0.75 \mathrm{kN}, 0.90 \mathrm{kN}$, $1.30 \mathrm{kN}$ and $1.05 \mathrm{kN}$ (ii) $0.80 \mathrm{kN}, 1.05 \mathrm{kN}, 1.65 \mathrm{kN}$ and 1.25 $\mathrm{kN}$ (iii) $1.20 \mathrm{kN}, 1.66 \mathrm{kN}, 2.18 \mathrm{kN}$ and $1.73 \mathrm{kN}$. It is clear that the load carrying capacity of the foundation increases with the increase in the density and also with the insertion of the reinforcement and it is optimum at $\mathrm{L} / \mathrm{D}$ ratio of 0.33 for all the densities. It is also clear that the bearing capacity of the footing increases with the number of reinforcement layers. Table 5 show that the values of ultimate load for three different densities, for different L/D ratio and for different layers. From table 5 it can be noted that the ultimate load carrying capacity is for density $17.36 \mathrm{kN} / \mathrm{m}^{3}$ for three layers for $\mathrm{L} / \mathrm{D}$ ratio 0.33 is $3.40 \mathrm{kN}$.

Table-5: Load carrying capacity values for various cases

\begin{tabular}{|c|c|c|c|c|c|c|}
\hline \multirow[t]{2}{*}{$\begin{array}{l}\text { Density } \\
\left(\mathrm{kN} / \mathrm{m}^{3}\right)\end{array}$} & \multicolumn{6}{|l|}{$\begin{array}{l}\text { Ultimate Load } \\
(\mathrm{kN})\end{array}$} \\
\hline & Unreinforced & No. of layers & $\mathrm{L} / \mathrm{D}=\mathbf{0 . 2 0}$ & $\mathrm{L} / \mathrm{D}=0.26$ & $\mathrm{~L} / \mathrm{D}=\mathbf{0 . 3 3}$ & $\mathrm{L} / \mathrm{D}=\mathbf{0 . 4 0}$ \\
\hline \multirow{3}{*}{16.57} & \multirow{3}{*}{0.22} & 1 & 0.5 & 0.60 & 1.05 & 0.74 \\
\hline & & 2 & 0.75 & 0.90 & 1.30 & 1.05 \\
\hline & & 3 & 0.90 & 1.40 & 1.83 & 1.23 \\
\hline \multirow[b]{3}{*}{17.16} & \multirow[b]{3}{*}{0.30} & 1 & 0.58 & 0.77 & 1.45 & 1.10 \\
\hline & & 2 & 0.80 & 1.05 & 1.65 & 1.25 \\
\hline & & 3 & 1.32 & 1.90 & 2.45 & 1.80 \\
\hline \multirow[b]{3}{*}{17.36} & \multirow[b]{3}{*}{0.40} & 1 & 1.03 & 1.42 & 1.70 & 1.51 \\
\hline & & 2 & 1.20 & 1.66 & 2.18 & 1.73 \\
\hline & & 3 & 1.50 & 2.04 & 3.40 & 2.28 \\
\hline
\end{tabular}

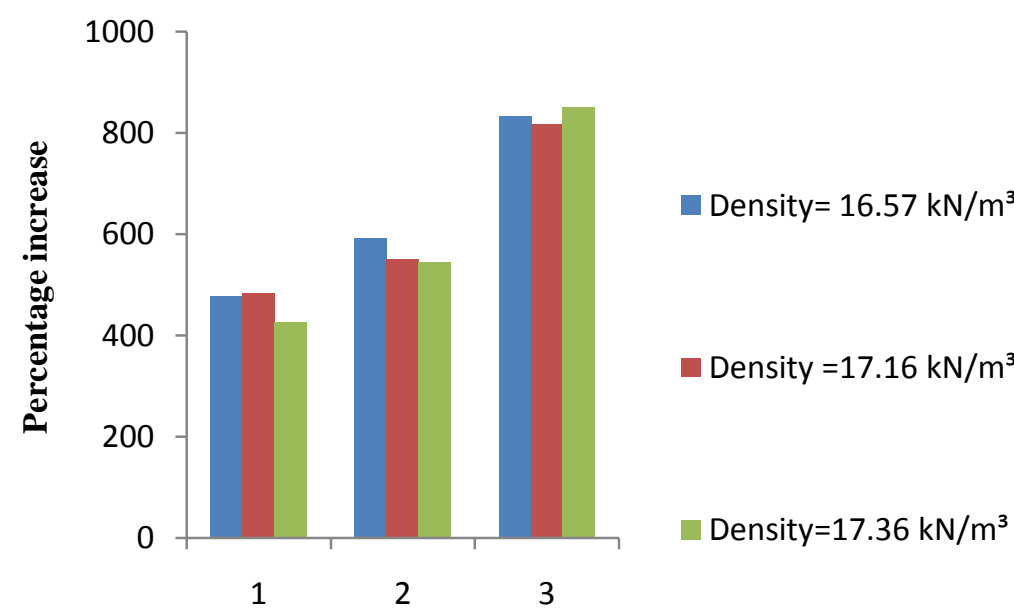

No. of layers

Fig-8: Percentage increase in load carrying capacity.

Table 6: Percentage increase in load carrying capacity of the footing for different densities and number of layers.

\begin{tabular}{|l|l|l|}
\hline $\begin{array}{l}\text { Density } \\
\left(\mathbf{k N} / \mathbf{m}^{\mathbf{3}}\right)\end{array}$ & No. of layers & $\begin{array}{l}\text { Percentage } \\
\text { increase }\end{array}$ \\
\hline \multirow{3}{*}{$\mathbf{1 6 . 5 7}$} & 1 & 477.27 \\
\cline { 2 - 3 } & 2 & 590.91 \\
\cline { 2 - 3 } & 3 & 831.82 \\
\hline \multirow{3}{*}{$\mathbf{1 7 . 1 6}$} & 1 & 483.33 \\
\cline { 2 - 3 } & 2 & 550.00 \\
\hline \multirow{3}{*}{$\mathbf{1 7 . 3 6}$} & 3 & 816.67 \\
\hline & 1 & 425.00 \\
\cline { 2 - 3 } & 2 & 545.00 \\
\cline { 2 - 3 } & 3 & 850.00 \\
\hline
\end{tabular}


Fig 8 shows the percentage variation with respect to number of layers for the density $16.57 \mathrm{kN} / \mathrm{m}^{3}, 17.16 \mathrm{kN} / \mathrm{m}^{3}$ and $17.36 \mathrm{kN} / \mathrm{m}^{3}$ and their values are tabulated in table 6 . The minimum and maximum percentage increase for the density $16.57,17.16$ and $17.36 \mathrm{kN} / \mathrm{m}^{3}$ is $477.27 \& 831.82,483.33 \&$ 816.67 and $425.0 \& 850.00$ respectively. It is clear that the load carrying capacity increases with the increase with the number of layers for all the densities.

\section{CONCLUSION}

The improvement in load carrying capacity of square footing resting on reinforced sand has been investigated through model plate load test in the laboratory. The results show that the ultimate load carrying capacity of square footing increases with the provision of plastic bottle as reinforcement. The optimum usage of plastic reinforcement can be used for density $17.36 \mathrm{kN} / \mathrm{m}^{3}$ for L/D ratio of 0.33 with three layers. Percentage increase in the load carrying capacity for the density $17.36 \mathrm{kN} / \mathrm{m}^{3}$ is $850 \%$. The increase in the load carrying capacity may be due to confinement to the soil as same as geocell.

\section{REFERENCES}

[1]. Dash, S. K., Krishnaswamy N.R and Rajagopal K. (2001)."Bearing capacity of strip footings supported on geocell reinforced sand", Geotextiles and Geomembranes, Vol.19, pp.235-236.

[2]. Dash, S. K., Krishnaswamy N.R and Rajagopal K. (2003). "Model studies on circular footing supported on geocell reinforced sand underlain by soft clay", Geotextiles and Geomembranes, Vol.21, pp.197-219.

[3]. Al-Aghbari, M.Y. (2007). "Settlement of Shallow Circular Foundations with Structural Skirts Resting on Sand", The Journal of Engineering Research Vol. 4, No.1 (2007) 11-16.

[4]. Sireesh, S, Sitharam, T.G and Dash,S.K., (2009). "Bearing capacity of circular footing on geocell -sand mattress overlying clay bed with void", Geotextiles and Geomembranes, Vol.27, pp.89-98.

[5]. Gupta, R and Trivedi, A. (2009). "Bearing capacity and settlement of Footing Resting on Confined Loose Silty Sands". Electronic Journal of Geotechnical Engineering, Vol.14, pp.1-14.

[6]. Moghaddas Tafreshi, S.N and Dawson, A.R. (2010) "Comparison of bearing capacity of a strip footing on sand with geocell and with planar forms of geotextile reinforcement", Geotextile and Geomembranes, Vol.28, pp.72-84.

[7]. Kumar.K.V.S.P, Venkata Koteswara Rao Pasupuleti and Satish Kumar Kolluru. (2012). "Bearing Capacity Of Square Footing on Geocell Sand Mattress Overlying Clay Bed". International Journal of Emerging trends in Engineering and Development, Issue 2, Vol.5, pp, 563-573.

[8]. Krishna. A, Viswanath B and Keshav Nikita (2014). "Performance of Square Footing Resting On Laterally Confined Sand" International Journal of Research in Engineering and Technology, Vol.03, pp, 110-114.

[9]. Ravi Gupta, Rakesh Kumar and P.K. Jain (2014). "Behavior of Circular Footing Resting On Two
Dimensionally And Three Dimensionally Skirted Foundations In Medium Dense Sand" International Journal of Advanced Engineering Research and Studies, Vol.3 pp, 45-47.

[10]. Ravi Gupta, Rakesh Kumar and P.K. Jain (2014). "Behavior of Circular Footing Resting On Three Dimensional Confined Sand", International Journal of Advanced Engineering Technology, Vol.5, Issue 2, pp, 1113.

[11]. Sareesh Chandrawanshi, Rakesh Kumar, Dr. Suneet Kaur and Dr. P.K. Jain, (2014), "Effect Of Skirt on Pressure Settlement Behavior of Model Circular Footing In Medium Dense Sand", International Journal of Advanced Engineering Technology, Vol. 5,Issue 2,pp,01-05.

[12]. Indian Standard - IS: 2720 (Part 3/See Indian Standard - IS: 2720 (Part 3/See 2) - 1980, "Methods of test for soils, determination of specific gravity, fine, medium and coarse grained soils", New Delhi, India.

[13]. Indian Standard - IS: 2720 (Part 4) - 1985, "Method of test for soils, grain size analysis-mechanical method", New Delhi, India.

[14]. Indian Standard - IS: 2720 (Part 13) - 1986, "Method of test for soils, direct shear test", New Delhi, India.

[15]. Indian Standard - IS: 1888 - 1982, "Method of load test on soils", New Delhi, India

\section{BIOGRAPHIES}

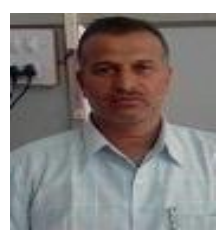

Dr P G Rakaraddi, He is presently working as an Associate professor in Civil engineering department, Basaveshwar Engineering College Bagalkot, Karnataka. He had post graduate in IIT Kharagpur. And also he got $\mathrm{PhD}$ in Soil Dynamics from IISc Bangalore.

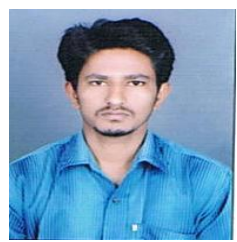

Sangameshwar Patil, Pursuing Post Graduation in geotechnical engineering at Basaveshwar Engineering College Bagalkot, Karnataka. 